Petersburg Only heterosexual men with no HIV, gonorrhoea, syphilis and $T$ vaginalis were enrolled in the study. CT infection was detected by in-house RT-PCR assay in St. Petersburg and confirmed in Amsterdam by a molecular test (TaqMan). The presence of HRHPV DNA in the studied samples was investigated in Amsterdam by the validated worldwide used GP5+/6+ assay.

Results The results are presented in the Abstract P3-S4.02 table 1. The overall CT and HPV prevalence in the study group was relatively high: $4.6 \%$ and $31.2 \%$, respectively. No significant correlations have been found between HR-HPV findings and CT status $(p=1.0)$.

Abstract P3-S4.02 Table 1 Detection of HR-HPV infection in 173 men with/without the history of $C$ trachomatis infection

\begin{tabular}{llllll}
\hline & $\begin{array}{l}\text { CT present, detected } \\
\text { during the study } \\
\text { (prevalence, \%) }\end{array}$ & & $\begin{array}{l}\text { CT in the past, history } \\
\text { of being infected } \\
\text { (prevalence, \%) }\end{array}$ \\
\cline { 2 - 3 } & CT+ & CT - & & CT+ & CT - \\
\hline $\begin{array}{l}\text { CT infection history } \\
173 \text { men, in total }\end{array}$ & $8(4.6 \%)$ & 165 & & $45(35.2 \%)$ & 128 \\
$\begin{array}{l}\text { HR-HPV infection, } \\
\text { detected in }\end{array}$ & $2(25 \%)$ & $53(32.1 \%)$ & & $14(31.3 \%)$ & $40(31.3 \%)$ \\
\hline
\end{tabular}

Conclusions Our study demonstrated: (1) CT and HPV prevalence among the Russian population can be high, (2) limited co-infection between HPV and CT infections: HR-HPV types were similarly often detected in both CT + and CT men, also regardless on their CT acquisition in the past, (3) CT history seems not to increase the HR-HPV acquisition, however, the association between HPV and C trachomatis infection still remains to be elucidated and follow-up studies especially among women or homosexuals. 4) All samples found RT-PCR CT + in Russia were confirmed CT + using molecular biological techniques in Amsterdam, showing the validity of CT detection in some settings in St. Petersburg. At the moment we additionally: (1) extent the study group, (2) investigate low-risk HPV detection and (3) perform immunogenetic analyses.

\section{P3-S4.03 IMPACT OF COMPREHENSIVE MANAGEMENT INCLUDING COUNSELLING ON HEALTH RELATED QUALITY OF LIFE INDEX IN INDIAN PATIENTS WITH ANOGENITAL WARTS}

doi:10.1136/sextrans-2011-050108.464

S Gupta. All India Institute of Medical Sciences, New Delhi, India

Background Health related Quality of life (HROOL) can be conceptualised as the absence of pain and an ability to function in day-today life. Our earlier study has shown that anogenital warts have an adverse effect on HROOL because of its impact on physical, psychological and sexual health, even though the lesions are often asymptomatic. ${ }^{1}$ To our knowledge, there are no studies available to show the impact of comprehensive management on HROOL of these patients.

Methods Thirty-five apparently healthy controls (meanage \pm SD $34.8 \pm 11.2$ ) and twenty patients with anogenital warts (mean age \pm SD $32.7 \pm 11.8$ years) were included in the study. HROOL of patients was evaluated using the WHOQOL-BREF instrument at the time of presentation and again after 4 months. During this period, all patients were comprehensively counselled by a trained counsellor and received regular treatment for anogenital warts. The questionnaire was available in local language (Hindi) and was self-administered.

Results All except two patients showed reduction in the size in response to treatment, however complete clearance was seen only in 10 patients $(50 \%)$. At the baseline, the HRQOL scores of patients were significantly lower than controls in all domains. The HROOL scores of patients after 16 weeks of comprehensive management were significantly higher than those at the baseline and comparable to those of controls (Abstract P3-S4.03 table 1).

Conclusion Comprehensive management of anogenital warts including counselling has resulted in the significant improvement in HRQOL scores. As anogenital warts are often asymptomatic, the effect on HRQOL appears to be due to its impact on psyche and fear of cancer and interventions including counselling can improve HRQOL more efficiently than in patients with other sexually transmitted diseases.

\section{REFERENCE}

1. Rama $\mathbf{R}$, Sreenivas V, Mehta $M$, et al. Health-related quality of life in Indian patients with three viral sexually transmitted infections: herpes simplex virus-2, genital human papilloma virus and HIV. Sex Transm Infect. Published Online First: 2 February 2011. doi:10.1136/sti.2010.043356.

\section{P3-S4.04 TOPICAL 80\% TRICHLOROACETIC ACID (TCA) SHOWS EFFICACY IN THE TREATMENT OF INTERNAL HIGH-GRADE ANAL INTRAEPITHELIAL NEOPLASIA (HGAIN)}

doi:10.1136/sextrans-2011-050108.465

${ }^{1} \mathrm{~K}$ Ho, ${ }^{1} \mathrm{E}$ Elishaev, ${ }^{1} \mathrm{D}$ Maciak, ${ }^{1} \mathrm{~J}$ Baker, ${ }^{2} \mathrm{C}$ Parzynski, ${ }^{2} \mathrm{C}$ Zhu, ${ }^{2} \mathrm{R}$ Day, ${ }^{1} \mathrm{R}$ Cranston. ${ }^{1}$ University of Pittsburgh, Pittsburgh, USA; ${ }^{2}$ University of Pittsburgh Graduate, School of Public Health, Pittsburgh, USA

Background HIV positive men who have sex with men (MSM) are at 60-70 times increased risk of developing anal squamous cell carcinoma than the general population. HGAIN, the putative precursor to cancer, may be ablated by various methods in order to prevent neoplastic progression. While TCA has previously been used clinically to treat keratinised external anal warts, it may also be used to ablate internal HGAIN. Here we report on treatment efficacy and clinical predictors of success.

Abstract P3-S4.03 Table 1 HROOL Scores in different domains of WHO0OLBREF of patients before and 16 weeks after comprehensive management and those of apparently healthy controls

\begin{tabular}{|c|c|c|c|c|}
\hline \multirow[b]{2}{*}{ HROOL domains } & \multicolumn{2}{|c|}{ Patients with ano-genital warts } & \multirow[b]{2}{*}{ p Value } & \multirow[b]{2}{*}{$\begin{array}{l}\text { Healthy controls } \\
\text { mean (CI) }\end{array}$} \\
\hline & $\begin{array}{l}\text { Before comprehensive } \\
\text { management mean (CI) }\end{array}$ & $\begin{array}{l}\text { After comprehensive management } \\
\text { (at } 4 \text { months) Mean (C.I.) }\end{array}$ & & \\
\hline Physical & 40.8 (32.3 to 49.3$)$ & 82.1 (77.9 to 86.3$)$ & $<0.001$ & 72.0 (63.70 to 80.30$)$ \\
\hline Psychological & 47.55 (37.8 to 57.3 ) & $78(71.6$ to 84.4$)$ & $<0.001$ & 68.9 (60.5 to 77.3$)$ \\
\hline Social & 45.05 (35.3 to 54.8 ) & 77.2 (70.8 to 83.6$)$ & $<0.001$ & 74.6 (68 to 81.2 ) \\
\hline Environmental & 51.35 (44.9 to 57.8 ) & 73.55 (16.4 to 130.7$)$ & $<0.001$ & 64.7 (58.5 to 71$)$ \\
\hline Total & 184.75 (157.2 to 212.3$)$ & 310.85 (294.7 to 327$)$ & $<0.001$ & 280.2 (253 to 307.5 ) \\
\hline Overall QOL & $2.65(2.2$ to 3.1$)$ & $4(3.4$ to 4.6$)$ & $<0.001$ & 3.5 (3 to 4$)$ \\
\hline Overall Health & 2.7 (2.3 to 3.1$)$ & 4.35 (4 to 4.7$)$ & $<0.001$ & $3.9(3.5$ to 4.4$)$ \\
\hline Sexual health & $2.95(2.5$ to 3.4$)$ & 4.15 (3.9 to 4.4$)$ & $<0.001$ & $4.2(3.8$ to 4.5$)$ \\
\hline
\end{tabular}

